\title{
THE RECONSTRUCTION OF DESTROYED NESTS BY POLISTES WASPS.
}

\author{
By Phil Rau, \\ Kirkwood, Mo.
}

Eight nests of $P$. pallipes and one of $P$. variatus were removed from the wall of a shed on July 21. The adult wasps were driven away when the nests were knocked down, but soon all of them settled again upon the old location of their homes. After only three days I found that each group had reconstructed its nest on the identical spot where the first one had been removed. Each of these nests already contained from 14 to 22 cells, and almost every cell contained an egg. Here, in case of hasty construction to replace a lost population, we see the economy in the method of building many shallow cells at first instead of few very deep cells. In the one nest of variatus, having seven adults, there were 22 cells. This shows that complete families, when disturbed, quickly rebuild, but notes elsewhere show that queens seldom do.

On June 15 and 16, when only queens were on the nests, all the station sheds along the railroad tracks were repainted; in the process, six new $P$. pallipes nests were knocked down at the station of Wickes, but not one was rebuilt that summer.

At Cliff Gave, on June 29th, I found a queen mother working on a newly begun nest with only six shallow cells. This tiny nest was unusual at this time of year, when all the other nests already had workers; but it showed at least that one queen did not lose courage in a calamity, but had the impulse to build anew.

A $P$. pallipes nest was knocked down from the ceiling of an open pavilion at Meramec Highlands in the latter part of July; on August 6 the wasps were busily rebuilding. I got the nest, and found it to be composed of shallow cells of less than onethird normal depth, 30 in all, and all but one containing an egg. Twenty of the cells contained also from one to three drops of various sizes of the transparent, jelly-like material described 
elsewhere. It is interesting to note that they made 30 cells onethird size instead of 10 full-sized cells, thereby giving the eggs the advantage of much-needed time at this late season, while the paper in all could be added from time to time as it was needed. This method is commonly followed by queens also.

On August 8, I took a nest and left four workers behind. The nest was rebuilt in the identical spot, and during the eight days following, twelve shallow cells were constructed; at the end of that time, each had an egg, and in the angle opposite the egg was a drop or two of clear honey. This seems an excellent accomplishment for four individuals in eight days.

One of these colonies of $P$. pallipes even made a third nest, when the second was taken down for study, but not on the identical spot; the third nest was placed two feet distant from the old site. 

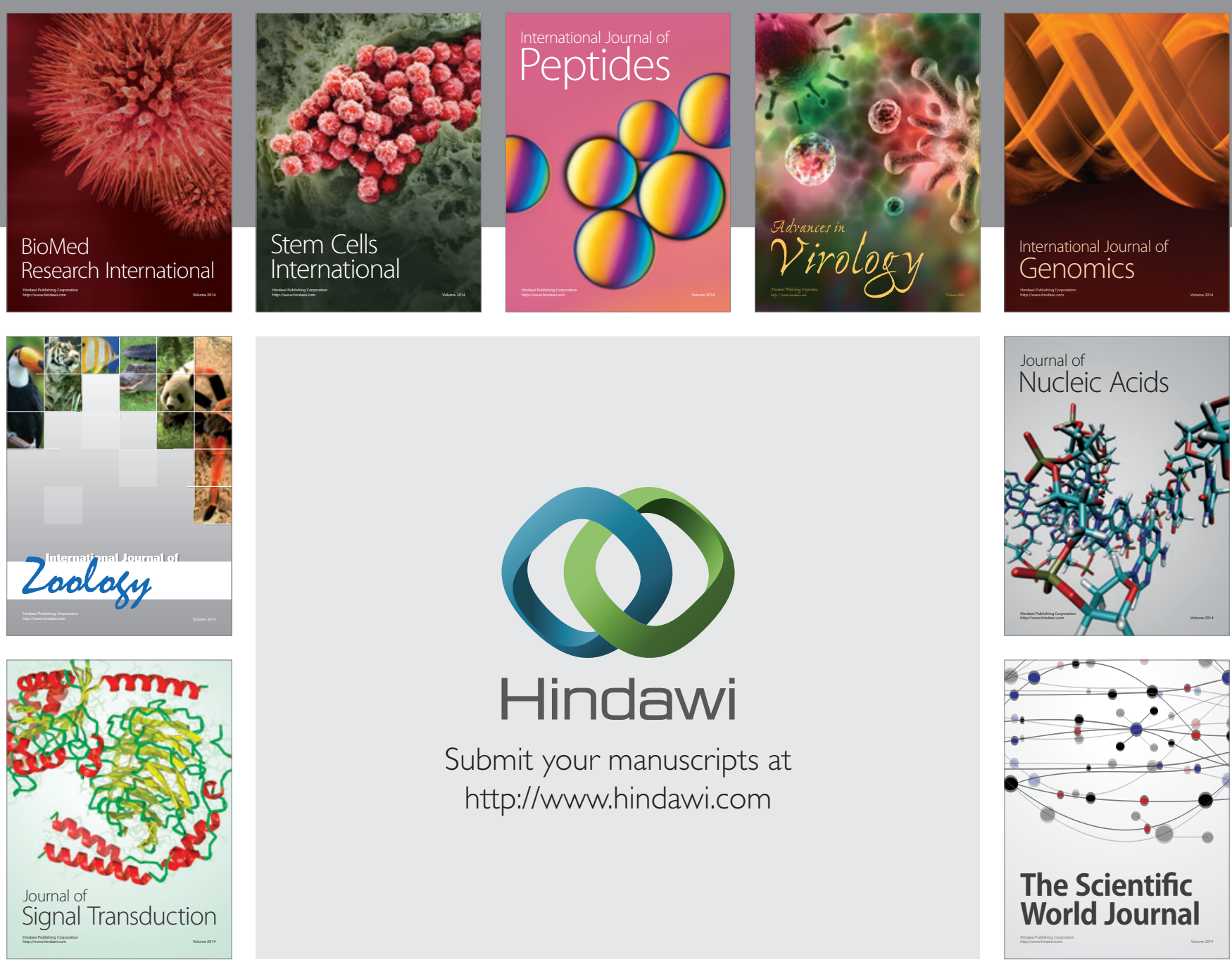

Submit your manuscripts at

http://www.hindawi.com
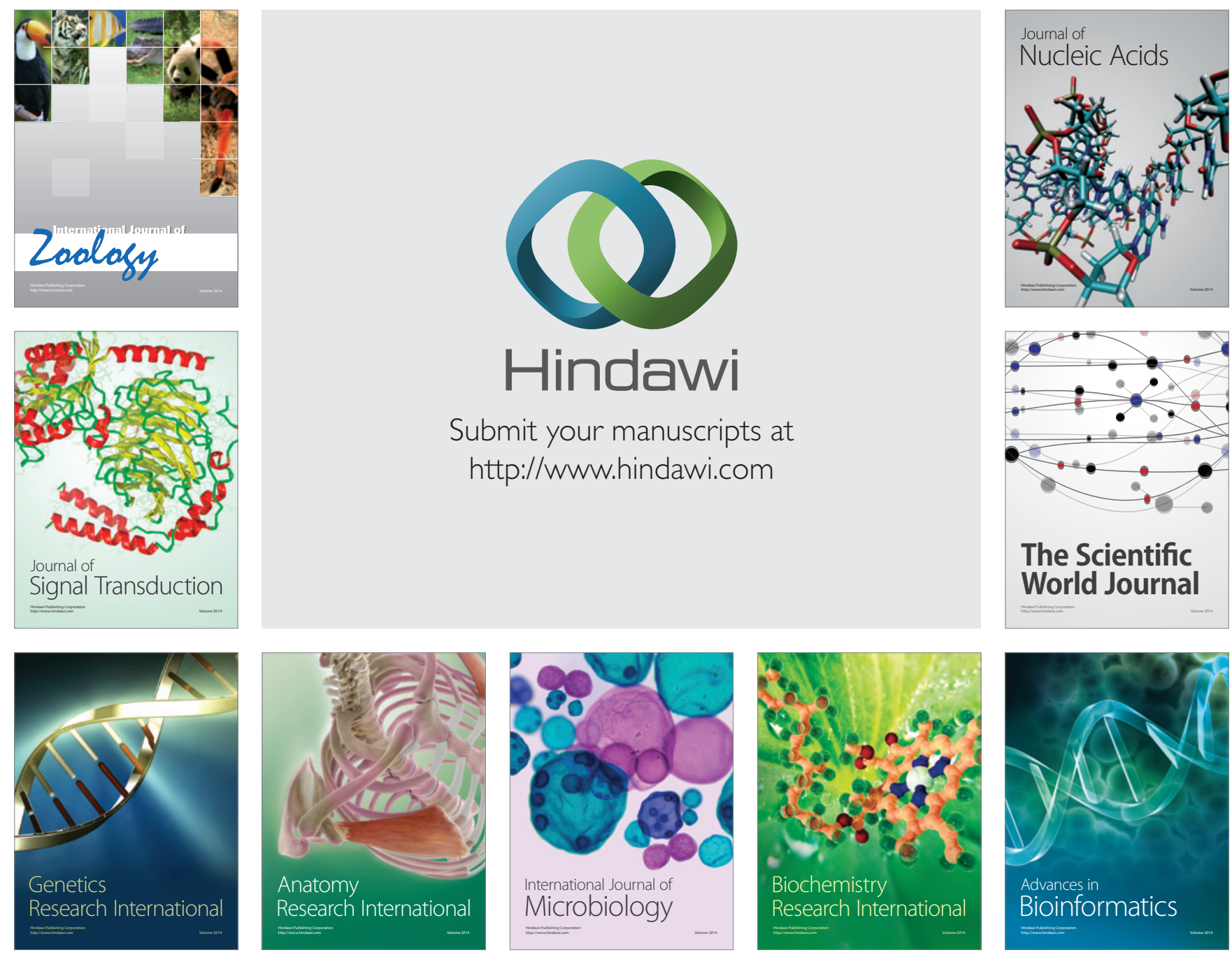

The Scientific World Journal
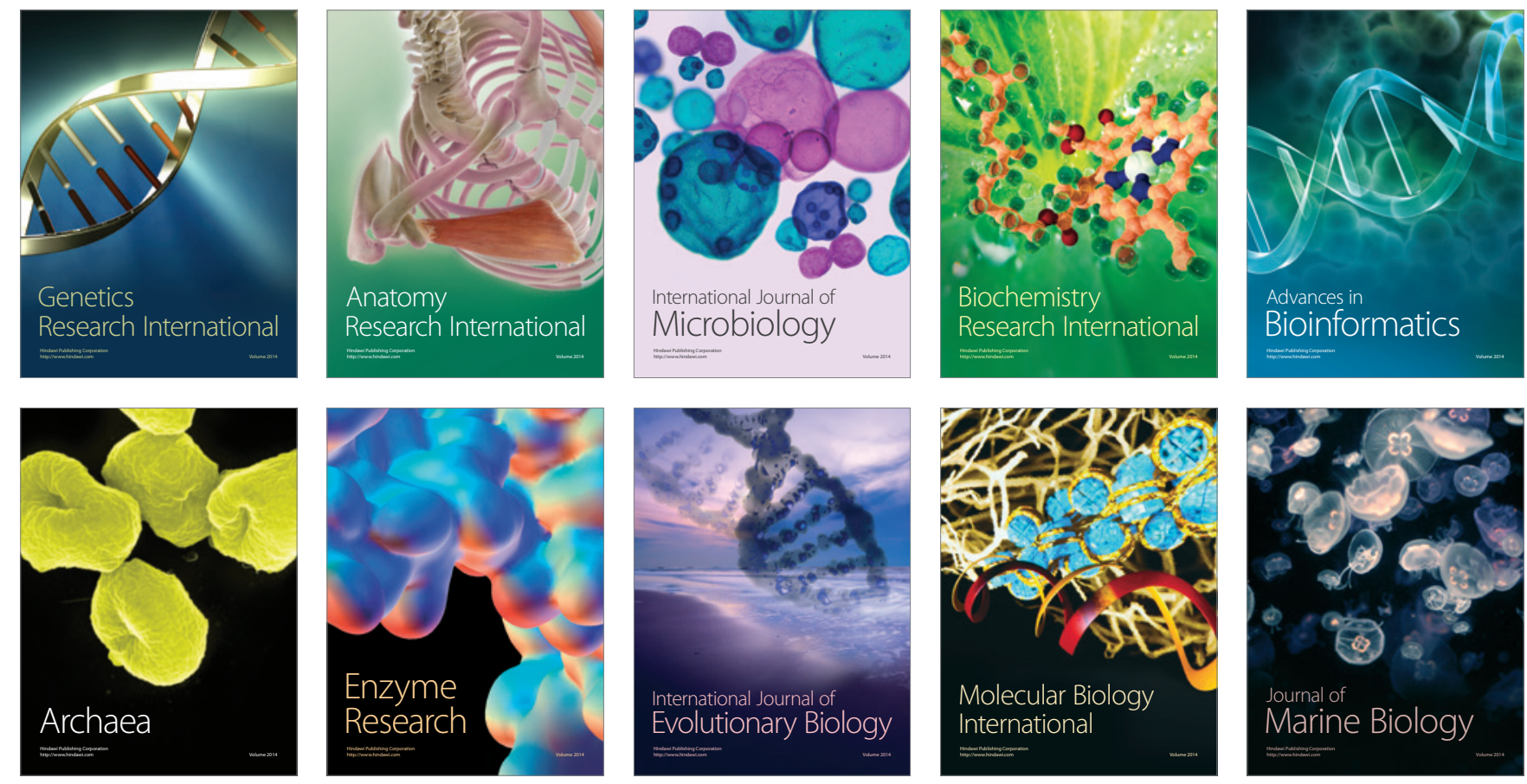